\title{
School management in improving quality education in SMA Nurul Ilmi Padangsidimpuan
}

\author{
Dunia Siagian', Kasman Rukun ${ }^{2}$, Sufyarma Marsidin ${ }^{3}$, Syafri Anwar ${ }^{4}$ \\ ${ }^{1234}$ South Tapanuli Institute of Education, Tapanuli - Indonesia, (duniasiagian2@gmail.com)
}

\begin{abstract}
The school management can mean everything pertaining to the management of the educational process to achieve the stated goals, both short-term goals, medium, or longterm goals. The purpose of term goal of this research was to determine the school management to improve the quality of education, to include: (1) Planning school programs; (2) The implementation of school programs and (3) Barriers faced. This study used a qualitative approach with descriptive methods. Subjects were principals, supervisors and teachers in primary schools Boarding School Jar Pidie district. Research results found: (1) planning school programs, (2) The implementation of school programs, and (3) Barriers in planning school programs. It is expected that supervisors in order to direct and supervise principals in improving the quality of education on school program planning, program implementation and obstacles faced by appropriate, effective and efficient so that the quality of education in the schools can be improved.
\end{abstract}

Keywords: managemen school

\section{Introduction}

The quality of education will be achieved if inputs, processes, outputs, teachers, facilities and infrastructure and costs are available and well implemented. However, from some of the components that play a role more is a quality teacher or quality (Sri Damayanti, 2008:). A teacher is required to be able to contribute enormously to education in the school environment, especially in terms of learning. Teachers play a central role in teaching and learning, therefore the quality of education in an educational institution is determined by the ability possessed by a teacher in carrying out his duties (Zainal Aqib, 2002: 22). Master is a very important component in improve the quality of education in schools.

Principal leadership ability is one of the main determinants of teacher empowerment and quality improvement of learning processes and products. The principal is the person most responsible for whether teachers and school staff can work optimally. School culture and learning culture are also built by the principal's leadership style in interacting with the community (Danim, 2005:9).The magnitude of the principal's responsibilities is described by Sergiovanni (1987:85) that is coordinating, directing and supporting activities related to his very complex task. The main tasks include formulating school goals and objectives, evaluating the performance of teachers and school staff, organizing and providing for teacher empowerment and improving the quality of learning processes 
and products. The principal is the person most responsible for whether teachers and school staff can work optimally. School culture and learning culture are also built by the principal's leadership style in interacting with the community (Danim, 2005:79).

The magnitude of the principal's responsibilities is described by Sergiovanni (1987:65) that is coordinating, directing and supporting activities related to his very complex task. The main tasks include formulating school goals and objectives, evaluating the performance of teachers and school staff, organizing and providing various sources of school organization, building and creating a psychological climate thatboth among members of the school community, building relationships with communities, planning together all school personnel and implementing other activities that support school operations.

Teachers as executive implementers of learning in schools must have professional skills. Therefore, the continuous development of teacher professionalism is absolutely necessary. One of the main means to improve teachers' professional skills is through education supervision. Educational supervision activities are an integral part of education management activities in schools. According Sergiovanni (1987:78) supervision is a conscious effort to stimulate, co-ordinate and guide continuously the growth of teachers in schools both individually and in groups to better understand and be effective in realizing all the learning functions. Furthermore, Depdikbud (1994:56) stated that the professional guidance of teachers is the provision of assistance to teachers, especially assistance in the form of professional guidance conducted by principals, supervisors, teachers or other facilitators to improve the process and results of teaching and learning.

Current educational supervision activities must be in line with decentralization of education. The long-established centralization system is assumed to lack the opportunity for teachers to freely plan, discover and develop learning. When viewed from the existing model of supervision approach, it would be more appropriate to refer to differential supervision approach (Wiyono, 2004:55). Differential Supervision is a supervisory approach that provides the choice of supervision services in the development of learning.

There are several reasons for the use of differential supervision. From a professional perspective, the teacher is a profession so that teachers need to be empowered by emphasizing the many options of supervision services. This type of supervision applies a different set of premises that allows teachers to have opportunities to develop themselves according to their characteristics and needs. In terms of organizational perspective, an effective school has a special climate that emphasizes the system of collegiality. The collegial environment provides many opportunities for interaction and creates great support expectations. While from the supervisory side, differential supervision will allow the supervisor to focus on the conscious effort appropriately in accordance with the needs of teachers and teachers can develop themselves optimally through techniques that Vary There are three methods of developing teacher development: intensive development, cooperative development, and self-development (Wiyono, 2004:44).

Intensive supervision is supervised by higher supervisors, either principals, vice principals, supervisors or senior teachers and is carried out continuously and systematically. The goal is more focused on teacher growth rather than teacher evaluation. Cooperative development is a process of teacher development through peers. A small team of teachers work together to facilitate their professional growth. This activity can be done through inter-class observation, professional dialogue, curriculum development, peer supervision, peer training, and action research. While selfdevelopment is the process of teacher growth through independent business independently. This activity is carried out through a model based on the objective or reverse diagnostic model so that teachers can identify weaknesses, set directions and techniques according to independently owned characteristics. This model can be done especially for teachers who already have a fairly high growth rate. 
This research was conducted at SMA Nurul Ilmi Padangsidimpuan which is categorized as good, that is SMA Nurulm Ilmi Padangsidimpuan. Both high school principals have a big share in the development of quality education. They have a strategic role in influencing teachers and school personnel to improve performance and bring about change, as well as in the improvement and improvement of the quality of education. Both schools have a reputation that is well regarded by the Department of National Education Padangsidimpuan associated with academic and non academic achievement.

\section{Method}

This research focuses on the guidance of teacher professionalism by the principal in improving the quality of learning in SMA Nurul Ilmi Padangsidimpuan. To reveal and describe the focus is necessary to observe the natural situation by using a qualitative approach (Bogdan \& Biklen, 1998 Denzin \& Lincoln, 1994:44). Through qualitative approaches can be generated an understanding of the substantive meaning of that phenomenon appearance, social events, and behavior of researched subjects related to research focus (Lincoln \& Guba, 1985).

This research was designed using multisite study design. Researchers act as instruments as well as data collectors (Lincoln \& Guba,1985; Bogdan \& Biklen, 1998:66). The presence and involvement of researchers in a research setting take two positions (Spradley, 1980): nonparticipant observation, and passive participant observation with overt appearance.

Determination of "sample" is done by purposive sampling technique (Bogdan \& Biklen, 1998). The use of this technique is realized according to the principle of funnel design, ie by collecting the data as wide as possible for later narrowing and sharpening according to the focus of research. Researchers searched and selected informants to obtain information appropriate to research objectives through snowball sampling technique (Patton, 1980:46).

Data collection techniques were conducted through: in-depth interviews, observations, and documentation (Bogdan \& Biklen, 1998; Yin, 1994; Denzin \& Lincoln; 1994; Marshall \& Rossman, 1989). While the data analysis used: (1) individual case data analysis at each school as subject of research, and (2) cross-case data analysis, which is a combination of findings that resulted from several research cases to find the similarities and differences of findings obtained on each case.

Checking the validity of findings and interpretation of data is done through tests of credibility, dependability, and data confirmability (Lincoln \& Guba, 1985; Moleong, 2002). The credibility test of the data is carried out by techniques: deep observation, triangulation of data sources and data collection methods, member checking, peer checking, and conformity tracking results (Patton, 1980). The dependability test aims to correct inaccuracies in the conceptualization of research plans, data collection, interpretation of findings, and reporting of research results. Confirmability aims to establish the objectivity of data and findings of research results in accordance with actual conditions in the field. The research activities are conducted through five stages: orientation studies on the context and background of the research, general exploration, focused exploration, examination of results and checking the validity of the research findings, as well as the research report writing stage.

\section{Results and Discussion}

\section{Exposure of Research Data Case 1: State Senior High School Padangsidimpuan}

Principals always support teacher learning practices. To support the principal's knowledge in understanding the learning practices through the headmaster working group, attending various activities to improve the quality of education and learning, to allocate funds to purchase books 
relating to improving the quality of learning. The principal uses the container to get the latest learning practice information programmed by the government and other schools. Principals also always follow various activities to improve the quality of learning practices both individually and together with teachers, such as workshops, seminars, training. Activities are usually implemented at least once a month. This is supported by the Managing BasicEducation (MBE) project which aims to improve the quality of school management in which one of its programs is to provide training to improve the professionalism of teachers.

The making of learning program and instructional innovation is done by the principal together with the teacher. Principals always share their knowledge with teachers especially in relation to learning both formally and informally. In order for the designed learning program to meet the needs and attract students' interest to learn, the principal gives teachers the freedom to practice and model the lesson.

Some of the learning practices applied by the State High School teachers of Padangsidimpuan include: individualization learning program, complete learning method, student grouping based on learning ability or achievement, learning resource center, team learning, free study, learning peers, direct learning methods, behavior modification, problem solving methods, evaluate learning, cooperative learning, and the use of people skilled in the field. The learning practice is tailored to the grade level.

The principal has the duty and responsibility to improve the success of school learning programs and the progress of teachers and students. This is done by the principal through the emphasis of a superior learning program, diagnosing continuous learning programs, discussing learning programs with teachers, and helping teachers solve classroom learning problems.

Principals are always willing to help teachers identify learning objectives and share ideas and experiences about curriculum and other learning problems. Teachers are given authority in developing syllabi and learning planning. Schools allocate funds so that the activities run as expected and give morale to the teacher. Another effort to improve the professionalism of teachers is to facilitate teachers to conduct classroom action research that aims to evaluate the teachers themselves about the learning process it does in the classroom. To improve the effectiveness of learning in the classroom, the school invited resource persons from outside the school by giving presentation and teaching consultation, ie officials of Diknas Padangsidimpuan, education experts from universities inside and outside Padangsidimpuan.

As a supervisor, the principal looks for learning topics and shares with the teacher. This effort aims to provide enrichment of learning materials through activities: searching for materials from the literature and training outcomes to create new learning methods, materials and evaluations; discussing learning topics in informal meetings; build a library of professional learning materials and encourage their use for teachers and other staff; buy a variety of tapes and VCDs to make it easier for children to understand the teacher's lessons; and encourage teachers to visit each other between classes.

To motivate teachers to carry out their tasks well, the principal takes note of teacher work satisfaction and a conducive working climate in schools. These efforts are made by establishing harmonious communication among school personnel, providing support and awareness and trust in teacher work, respecting teacher work, creating integrity between school learning programs and teacher-learning practices in the classroom, and creating renewed teacher-learning practices. Increased morale and teacher satisfaction help students learn so as to develop students' academic knowledge, skills, attitudes, and grades. 
To streamline the learning program, the principal establishes a group or teacher advisory team that serves to advise the principal about applied learning practices and help solve learning problems before being taken to teacher board meetings. This team consists of senior teachers who have competence according to their field.

Improving the quality of learning is done by the principal through various techniques of teacher professional development or supervision. The main purpose is to help teachers improve their teaching performance so as to improve student learning. The supervision techniques are individual and group, which include: class visits, personal meetings, regular meetings, inter-school visits, group work meetings, and training and upgrading.

Evaluation of learning done by the principal by looking directly at the process of learning in the classroom or class visits. Class visits are scheduled and unscheduled, at least once a week, the principal goes from one class to another. The purpose of this visit relates to teachers' principal attention to teachers and assistance to teachers if they are learning problems rather than looking for teacher misconduct. This activity is also to control student discipline.

Personal meetings are held by the principal as a follow-up of class visits. This meeting is usually done to help teachers solve problems in the classroom where the teacher does not want the problem are discussed in teacher meetings. Teachers more freely express the problem because the atmosphere is informal and relaxed. The principal does not specifically schedule this activity. Personal meetings are also aimed at helping new teachers who do not have teaching experience. The principal gives orientation and guidance to the new teacher so that later he can do his job well. The meetings are usually done once a week. The principal is obliged to help new teachers master teaching skills.

While formal meetings are regular meetings between principals and teachers conducted once a month with the aim to evaluate the implementation of teaching and learning in the classroom. Formal meetings can also be done at any time if there are problems that must be solved immediately. This routine meeting provides an opportunity for teachers to conduct self-evaluation about the work that has been done so as to motivate teachers to further improve productivity. Other activities to improve the quality of learning are done by programming inter-school visits or comparative studies. This program is intended to enable teachers to have a broad knowledge of the superior learning programs implemented by other schools. The comparative study was conducted not only within the province but also outside the province.

In each school cluster there is a working group. The formation of working groups is tailored to the field of duty of each teacher. This school established a working group because this school is one of the core schools in Padangsidimpuan City. The working groups include the Principal Working Group, the Religious Teacher Working Group, the Sports Teacher Working Group and several Mathematics Teacher Councils. Each working group regularly holds monthly meetings that serve to solve the learning problems faced by principals and teachers in each school.

The school program develops the competence and qualifications of teachers to improve teacher professionalism. The principal encourages teachers to attend and participate in various programs inservice training, ie workshop, seminar, training, upgrading to update teacher's knowledge in learning. For teacher qualification programs, schools facilitate teachers to follow priority studies that are prioritized for teachers who still do not have a Bachelor's degree. Teacher's interest to continue at undergraduate level is very high, even this school already has two master's degree master.

In order for teachers to run effectively, the principal involves senior teachers to help teachers solve learning problems. The assistance provides teachers with opportunities to apply new learning 
methods that can improve student achievement. The assistance was effective in increasing teacher awareness of the advantages and weaknesses in learning.

Data or information collected through supervision techniques and evaluation of learning reflects teacher performance. After all the data collected then the principal then provide the data to the teacher to be studied. As a follow-up, principals and teachers held meetings to discuss the information. Meetings usually depend on teacher demand both informally and formally.

Based on the evaluation of the learning, the principal can determine the level of teacher performance, whether the performance level is high or low. If the teacher's performance level is low then the principal will help the teacher to improve it through continuous coaching.

\section{Exposure of Research Data Case 2: SMA Nurul Ilmi Padangsidimpuan}

As a supervisor, Head of State Senior High SMA Nurul Ilmi Padangsidimpuan perform various activities to advance school learning program. Some of these activities include setting goal achievement, participating in a learning program, expecting the best work from the teacher, controlling the implementation of the curriculum and school programs. Achievement of goals is done through targeting which includes: more transparent school management; increased cooperation with school committees, class associations, community leaders, relevant agencies, and student guardian; improvement of teacher discipline and responsibilities; optimizing teaching and learning activities characterized by PAKEM; teacher professionalism is increasing; and the optimization of school and class autonomy.

Principals help teachers identify learning objectives, share ideas and experiences about curriculum and learning. In order to create an effective learning program, the principal provides wide opportunities for teachers to create innovative and superior learning by giving each teacher the freedom and authority to make learning plans.

In every meeting with the board of teachers, the principal emphasizes the quality of education. The principal expresses the importance of the materials, methods and instructional tools used by the teacher according to the curriculum requirements. For material enrichment, principals with teachers and school committees increase the quantity and quality of school and class library books. Special class libraries, in addition to funding allocations from schools, classrooms also help contribute textbooks and general books for their children.

Improving the success of the learning program is done through the emphasis of superior learning programs, diagnosing continuous learning programs, discussing with teachers, and assisting teachers in solving various classroom learning problems. The principal encourages teachers to apply various models of learning in the classroom and authorize teachers in doing their work, for example: applying new and innovative learning methods, using media and learning evaluation methods. The principal acts as a teacher's work partner in learning.

Giving authority of teacher learning practice aims to meet the needs and attract student learning interest. Some of the learning practices that have been done include: individualized learning, cooperative learning, complete learning method, learning resource center, student grouping based on achievement, team learning, free study, peer learning, direct learning method, problem-solving method, evaluating learning, and the use of professional sources.

Improving the quality of learning is also pursued by the principal provide learning management assistance for teachers through cooperation with resource persons from outside the school. The cooperation is conducted with the Office of National Education District and Province. This is because 
this school is one of the schools designated as pilot project (pilot project) School-Based Management (school-based management) national level.

The principal's effort to improve student learning is through the creation of teaching methods, materials and evaluations for teachers from literature, research outcomes and seminars and training. The principal also holds meetings with teachers both individually and in groups informally, and creates a reading culture among teachers by building libraries containing innovative learning books.

Teacher work satisfaction and a conducive working climate for the learning process become the principal's main concern to improve the quality of learning. The creation of teacher work satisfaction and a conducive working climate for the learning process is conducted through open and honest communication among school personnel, providing support and confidence to the teacher's work, integrating school programs with lessons learned by teachers in the classroom. Efforts to create employee morale are applied by providing other incentives when the teacher completes the work outside of the assigned task, and rewards outstanding teachers through the selection of exemplary teachers.

In order to create effective communication, the principal provides opportunities for teachers to hold meetings both formally and informally to discuss issues related to learning. This activity provides an opportunity for principals and teachers to be open to each other in evaluating themselves about their respective roles.

While the professional guidance of teachers in particular by the principal is done with some supervision techniques. The supervisory techniques performed by the principal are individual and group, ie class visits, private meetings, regular meetings, inter-school visits, group work meetings, and training and upgrading.

The principal makes a class visit by observing directly into the classroom during the learning process. Class visits are preceded by an agreement between the principal and the teacher. The class visit is more scheduled given the busyness of the principal and is usually done on a regular basis once a week.

This supervision technique aims to assist the teacher when experiencing difficulties in the learning process that takes place in the classroom. The class visit is not to seek teacher weakness, but to improve the performance of teachers in carrying out their work. Class visits are more focused on things that are substantive rather than administrative.

The principal then holds a private meeting as a follow-up of the class visit. Personal meetings allow teachers to express learning problems faced in the classroom more openly. Usually private meetings are held at breaks and after the learning process is completed in the classroom. This supervision technique also aims to help new teachers who do not have the experience of teaching or prospective teachers who apprenticed in this school.

The school principal's guidance to new teachers aims to help new teachers not only to master their teaching skills in the classroom but also to help them apply the basics of classroom management, to planning lessons and implementing learning evaluations. The pattern of teacher and student interaction in the learning process in the classroom becomes the focus of attention of the principal's guidance to the new teacher. Another supervision technique that is often done by the principal is a regular meeting of the principal with the board of teachers. This meeting is held once a month in the first week. The meeting aims to discuss the learning program that has been and will be implemented. Any decision-making associated with school development, principals always involve school personnel. The principal emphasizes the implementation learning in accordance with the allocation of 
time, making learning planning and evaluation tools, and the deepening of the subject matter of each teacher.

To enrich the experience of teachers in learning development and innovation, schools program comparative study or inter-school visits. The principal schedules an appeal study at least once a year. The object of the comparative study is tailored to the objectives to be achieved and the budget set. This comparative study activity is very interested in the teacher, in addition to adding knowledge as well as excursions.

SMA Nurul Ilmi Padanfsidimpuan is one of the core elementary schools in Maron Sub-district. Schools facilitate teachers by empowering established working groups, eg KKKS (Principal Working Group), MGMP (Mathematics Teacher Conference). Regular group meetings are usually held once a month in SMA Nurul Ilmi Padangsidimpuan and occasionally implemented in turns from one school to another school.

The school program develops the competence and qualifications of teachers to improve teacher professionalism. Teacher competency development is done by encouraging teachers to attend and participate in various training programs, such as seminars, workshops, upgrades, workshops. This activity aims to update teachers' knowledge in learning. The assignment of teachers in competency development activities is done by allowing all teachers to take turns so that all teachers will gain the same understanding.

As one of the schools used as a government pilot project, SMA Nurul Ilmi Pdangsidimpuan many teachers have the opportunity to participate in teacher competence development program through various training. Almost all teachers have acquired the latest knowledge of learning programs. There are even teachers who are assigned as one of the facilitators of the national-level learning program.

Professionalism of teachers is also done by the school through advanced courses to meet the qualifications of faculty. Therefore the principal facilitates the teachers to follow the advanced study. Further study programs are given to teachers who do not have a bachelor's degree. High teacher motivation and interest to follow up study due to government demand that elementary school teacher must have minimum undergraduate qualification. Implementation of supervision will be effective if done not only by the principal. Therefore, principals involve senior teachers in supervision activities. Teachers feel helped by this policy because of the involvement of senior teachers making teachers feel there are no psychological barriers in supervision activities. Teachers can communicate openly and share experiences and exchange ideas more freely in solving learning problems.

After all the supervision is done, the principal and teachers meet to discuss the results of the supervision. This evaluation is important in order to find solutions for improving teacher professionalism. The principal improves teacher performance in learning through coaching both internally at school and from outside school. Many teachers feel helped by this activity.

The principal as a supervisor should have extensive knowledge and learning insights. Understanding the principal on classroom teaching practices can increase his or her responsibilities as a supervisor where the teacher expects the principal to provide the learning assistance he does in the classroom. Understanding of principal's learning practices is done through several activities: headmaster group meetings, participation in various scientific activities, training, comparative study to achieving schools and procurement of textbooks.

A principal in a school that effectively fosters school goals, participates in a learning program, expects students and teachers to do their best, has curriculum control, and is seen as a supervisor. A person can become a learning supervisor by acquiring knowledge and sharing with teachers and others involved with student learning (DeRoche, 1985:61). According to Smith and Andrews (1989) 
the principal can undertake several activities that include: demonstrating the ability to evaluate and reinforce appropriate and efficient learning strategies; supervising staff, using strategies that focus on improving learning; in the process of assessing the educational program, the principal uses the information of graduate students directly related to the learning problem; demonstrating success in implementing personnel evaluation policies; and know the importance of student learning objectives in the implementation of learning programs.

Principal understanding of instructional practices can lead teachers to create a superior learning program and apply learning models according to student characteristics. The willingness of the principal to share knowledge with teachers can gain support and input for the development of learning programs. The principal also provides the authority and freedom of teachers to do their work so as to enhance the effectiveness of learning because it is tailored to the needs and interests of student learning.

The principal as a learning leader is responsible for the success of the overall learning program. The improvement of the success of the learning program is carried out by the principal through discussions or sharing of experiences with teachers, diagnosing continuous learning programs and helping teachers solve classroom learning problems.

To improve the professionalism of teachers, principals provide coaching and training to teachers, such as classroom action research training. Implementation of coaching and training is done in cooperation with experts both from the local education office and with the college. In addition, schools also collaborate with various institutions to make a great contribution in developing and improving school programs. Schools will not develop without cooperation with outsiders.

As a supervisor, the principal should be able to provide learning topics for teachers. Some learning topics can be obtained through library materials and training outcomes, informal meetings with teachers to discuss learning issues, build professional libraries, and display the work of teachers and students inside and outside the classroom (DeRoche, 1985:65). Various learning topics can be selected by the teacher to provide the best service to students.

The work of a principal is described as the practice of solving problems. Knowledge needs to be given by the principal, because professional activity is not routinely inculcated in organizational culture. Thinking daily or thinking practically is a term used to describe a mental process performed like a problem-solving leader (Leithwood, 2002:45). The use of past knowledge of leaders can be considered in practical thinking to solve problems in the classroom and school (Scribner, 1984). Problem solving by the principal depends on the readiness of broad access to knowledge in accordance with the problem. Knowledge of problem solving requires the skills and participation of others.

The contribution of the active participation of others and the problem solving knowledge substantially enhances the individual development of a leader (Leithwood and Steinbach, 1995:28).

Teacher's encouragement to do her job well is driven by teacher work satisfaction and conducive working climate. The principal has the duty and responsibility to improve teacher work satisfaction and a conducive working climate for school learning through the creation of open and harmonious communication among school personnel, respect for and confidence in teacher work, integrating school learning programs with classroom teaching practices. Teacher work satisfaction and a conducive working climate can encourage teachers to do their job well (Hoy \& Miskel, 1987:32).

Communication by the principal openly creates a sense of togetherness among school personnel. As a communicator the principal performs six activities (Smith \& Andrews, 1989), which are: (1) demonstrating the ability to effectively evaluate and relate to other people, for example, making proper, sensitive and reliable two-way communication, (2) speaking and writing clearly and bright, for example displaying organizational skills in oral and written communications, (3) using 
satisfactory conflict management skills and strategies, such as the ability to help others find acceptable solutions, (4) facilitating groups in selecting action issues through problem-solving techniques, such as identifying and collecting valid, relevant and reliable information, (5) demonstrating the ability to use a variety of group process skills in interaction with staff, parents and students, for example helping others develop commitment to the process of achieving goals, (6) demonstrating skills in $\mathrm{b}$ working as team members, for example assessing the strengths and weaknesses of team members.

Provision of incentives for teachers who complete the work outside of their duties, awards to gureu-teachers who have a commotment in carrying out their obligations and have achievements in leading the learning in the classroom can improve job satisfaction and teacher morale. In addition, awards are also given to teachers in the three background research in fostering students to attend various academic and nonakademik competitions. This is done by the principal to provide motivation to teachers to provide the best service to students (Maslow, 1987:67).

Informal meetings between school principals, teachers and other school personnel to discuss learning issues can create openness in self-evaluation so as to enhance job satisfaction and teacher morale. Informal meetings provide a broad opportunity for teachers to share in solving learning problems.

According to Davis and Thomas (1989:48) there are several conditions that can improve teacher performance including commitment, effort and job satisfaction of teachers. Conditions that can support the performance of teachers are: the level of student achievement high school opportunities, teacher opportunities to teach according to their subject, significant feedback on teachers' efforts to influence student learning, low levels of disturbance and poor student behavior, opportunities for teacher leadership in schools, high teacher support levels, greater teacher participation in decision making schools, clear links between student change and welfare initiatives, avoiding excessive emphasis on evaluation and accountability in particular simple performance assessment techniques, teacher awards about employment and career opportunities, teacher assistance, especially new teachers, grouping with other teachers, adequate and other learning resources in the classroom, high class autonomy level, improved learning program coordination, professional teacher development opportunities, and relatively high pension funds. Diversity, complexity and high uncertainty in the workplace can remove commitment, effort and teacher satisfaction.

On supervision techniques conducted by the Head of State Senior High School Padangsidimpuan to improve the professionalism of teachers include class visits, private meetings, regular meetings, visits between schools, meetings in working groups, and training and upgrading. Class visits conducted by the school principal on a regularly scheduled or unscheduled basis can help teachers solve learning problems in the classroom. One of the strong characteristics of supervisors is classroom visits where the purpose of the activity is to improve learning supportively and constructively for the teacher so as to improve learning and evaluate teachers (Ubben \& Hughes, 1992;:34 Sergiovanni, 1987:67).

There are six characteristics of a successful principal (Davis \& Thomas, 1989:54). These six characteristics include: having a strong vision of what the school can do and encouraging all school personnel to realize the vision; have high expectations of student achievement and staff performance; observe teachers in the classroom and provide positive and constructive feedback with the aim of solving problems and improving learning; encourage the use of efficient learning time and designing procedures to minimize disturbance; using creative material and material resources; and monitor student achievements individually and collectively and use information to guide learning planning.

Personal meetings are an effective supervisory technique in which teachers more freely express the problems faced more openly. These activities are performed unscheduled because of the busyness of the principal and in accordance with the needs of teachers. Such private meetings are an effective 
forum for discussing teacher learning. Teacher development with this technique can also help new teachers who have not experienced teaching in schools to master teaching skills, make learning plans, evaluate learning, apply classroom management, and understand student behavior (DeRoche, 1985:43).

Regular meetings between school principals and teachers conducted once a month can improve the learning program based on the results of evaluation of the implementation of learning that has been done by the teacher. Regular meetings between school personnel and school committees also help principals develop educational programs in schools. Such regular meetings can increase the participation and support of parents for school success by involving all school personnel in any decision-making. In the context of site-based management, parent participation is crucial to school success (Leithwood, 2002:54).

The supervision techniques that are usually scheduled by the school are inter-school visits or comparative studies. The visit aims to improve understanding and refreshment for teachers on learning practices and learning innovations conducted in other schools. This technique is useful for improving the effectiveness of teacher learning practices (DeRoche, 1985:82).

Teacher development can also be done with the formation and empowerment of work groups where teachers are given the freedom of teachers to discuss learning problems faced in the classroom. According to Davis and Thomas (1989:81) teachers can work together in improving the professionalism through work groups or teams of teachers who meet every week or day to solve problems or plan and implement new learning and learning methods, and through teacher activity centers where a group of teachers share problem solving and skills or learning workshops directed by an expert or professional teacher other. Therefore, teachers need to utilize the existing working groups in each of the primary school clusters. There are five functions of the formation of elementary school clusters (Bafadal, 2003:94), namely the infrastructure of professional capacity building of educational personnel; as a vehicle for dissemination of information and innovation in the field of education for educational personnel; the vehicle fosters the spirit of cooperation and competition among school cluster members in improving the quality of schools; the unifying container of the soul of unity and unity and foster the confidence of teachers, principals, supervisors, and coaches in completing tasks; and can be used as a forum for increasing community participation.

Teacher professionalism improvement is also done through two programs, namely teacher competence development program and teacher qualification. Teacher competency development programs are conducted by involving teachers to participate in various scientific activities, such as seminars, training, workshops. According to Hallinger and Murphy (1987:76) a principal can plan and monitor the teacher's development opportunities as well as gain teacher feedback on the training materials. The principal actively and supportively helps the teacher learn to use the new learning approach, and sets expectations of curriculum quality through the use of standards and guidance.

While the qualification of teachers is done by following the advanced study to the undergraduate level for undergraduate teachers. There are three objectives of teaching tasks to teachers in primary schools: (1) increasing the formal qualifications of teachers so that they are in accordance with the national-level employment regulations and the foundations that overshadowed them; (2) enhancing the professional skills of primary school teachers in order to improve the quality of education in primary school, and (3) developing the motivation of primary school employees in order to improve their performance (Bafadal, 2003:56).

The involvement and assistance of senior teachers solve problems faced by teachers can improve the effectiveness of the implementation of the supervision of learning because teachers feel no psychological barriers. According to Davis and Thomas (1989) the process of peer supervision is more informal and relaxed. This does not require open stages and procedures, because peer supervision is always voluntary, there is never any intervention to protect the rights of teachers. Peer supervision is 
more effective and efficient than tiered supervision by the principal. Master feels more free to experiment. Supervisor must have empathy and have high credibility. In applying peer supervision, the principal takes into account the key teachers for his leadership success. Leadership is run through actions or duties to others to achieve organizational functions (Spillane, 2000:67).

\section{Conclusions}

The principal has a duty to improve the overall success of school learning programs and the progress of teachers and students. This is done by the principal through the emphasis of a superior learning program, diagnosing continuous learning programs, discussing learning programs with teachers, and helping teachers solve classroom learning problems. Principals are always willing to assist teachers in identifying learning objectives and sharing ideas and experiences with teachers about curriculum and other learning problems.

The principal provides professional coaching of teachers with various techniques. The main purpose of the coaching is to help teachers improve their teaching performance, which will ultimately improve students' learning. The supervision techniques performed by the principal are individual and group. The supervision techniques include: class visits, private meetings, regular meetings, interschool visits, group work meetings, and training and upgrading.

\section{References}

Bafadal, I. (2003). Peningkatan Profesionalisme Guru Sekolah Dasar. Jakarta: PT Bumi Aksara.

Bogdan, R.C. \& Biklen, S.K. (1998). Qualitative Research for Education: An Introduction to Theory and Methods. Boston: Allyn and Bacon, Inc.

Danim, S. ( 2005). Menjadi Komunitas Pembelajar: Kepemimpinan Transformasional dalam

Komunitas Organisasi Pembelajaran. Jakarta: Bumi Aksara.

Davis, G.A. \& Thomas, M.A. ( 1989). Effective Schools and Effective Teachers. Boston: Allyn and Bacon.

Denzin, N.K. \& Lincoln, Y.S. (1994). Handbook of Qualitative Research. Thousand Oak, California: Sage Publications, Inc.

Depdikbud. (1994). Pola dan Strategi Pembinaan Pendidikan. Jakarta: Depdikbud Direktorat Pendidikan Dasar.

DeRoche, E.F. ( 1985). An Administrator's Guide for Evaluating Programs and Personnel: An Effective Schools Approach. Boston: Allyn and Bacon.

Hallinger, P., \& Murphy, J. 1987). Assessing the Instructional Management Behavior of Principals. Elementary School Journal, 86 (2), hal. 217-247.

Hoy, W.K., \& Miskel, C.G. ( 1987). Educational Administration: Therory, Research, and Practice. New York: Random House.

Leithwood, K. A. \& Steinbach, R. (1995). Expert Problem Solving: Evidence from School and District Leaders. Albany, NY: State University of New York Press.

Leithwood, K.A. ( 2002). Organizational Learning and School Improvement. Greenwich, CT: JAI.

Lincoln, Y.S. dan Guba, E.G.L. ( 1985). Naturalistic Inquiry. Beverly Hill, California: Sage Publications, Inc.

Marshall, C. \& Rossman, G.B. (1989). Designing Qualitative Research. Newbury Park, California: Sage Publications, Inc. 